\title{
SUCCESS AND FAILURE OF THE SOCIOLOGY OF CULTURE? Bringing the arts back
}

\author{
Vera L. Zolberg*
}

\begin{abstract}
This articles brings up the most recent, internal discussions among researchers in the field of the sociology of arts, more precisely the thiking of experts who participated in a forum of culture organized in 2001. In her writing, Vera Zolberg accentuates, overall, the need for sociology of art to retain both its humanistic and scientific roots. She reminds that sociology of culture has developed from the sociology of art in recent decades. Next, she summarizes the tendencies and interests of researchers in the forum, by showing the fluidity of its possibilities and creative capacities. She mentions the most recent production in the field, proving that aesthetic elements play a crucial part in the sociological studies about the arts. According to Vera Zolberg, it is time to bring the arts back
\end{abstract}

Key-words: Sociology, arts, culture, society and flexibility

Every once in a while we should take a look at the substantive character of our field, the sociology of culture. Several of us did that in response to the invitation of Diana Crane, who organized a "culture forum" on the occasion of the Eastern Sociological Society meeting in Philadelphia in March of 2001. She encouraged us to try to discern the "cutting edge" of the sociology of culture, and the excitement generated by the occasion, the large audience it attracted, and the variety of reactions to her summons were gratifying to say the least. We need to remember that a little less than two decades earlier, a handful of American Sociological Association members had to put

\footnotetext{
* Sociology Department, New School for Social Research. Artigo recebido em 23 mai. 2005; aprovado em 6 jul. 2005.
} 
considerable effort to convince one hundred other members to sign the petition needed to begin the process of establishing a new ASA section on culture. Its growth since then must have come as a surprise to some American sociologists. How could a discipline that was destined by some of its founders to be an exact science come to be mixed up with the sorts of questions and frameworks that have now attracted the attention of hundreds of ASA members?

At the time, some of us wanted to treat political, economic, institutional structures and practices as texts to be read; others sought to understand science and technology as cultural and social constructions, arguing that science was no more "objective" or "out there" than the arts; others focused on the interaction of networks and cultural meanings; the social construction of collective memory, or of identity.

It is not that these questions were completely new to American sociology. What was new was our insistence that sociology has something to offer in the process of answering them. The answers were sought in frameworks and perspectives that might be cognitive, comparative historical, symbolic, or conceptualizations imported from other disciplines. Our hope was that we retain both our humanist and our scientific roots. Richard Peterson's appeal that we meld ethnographic and humanistic definitions of culture argues in the same mode (Peterson, 1992, p. 10-11). My own writings on the sociology of the arts call for sociologists to strive for a similar practice. They acknowledge the necessity of straddling the plurality of intellectual orientations in order to contribute both to academic concerns and to the conversations that need to continue between the social scientific communities and the world (Zolberg, 1990).

By now, what has been true all along, that culture is a deeply embedded component of sociology, has come to be accepted with little opposition. Sociologists may deal with science, theory, macrohistorical questions, education, religion, ethnicity, and more. In recent years sociologists have abandoned reified categories in favor of the more difficult terrain of investigating the construction process itself. 
Going beyond simple base-superstructure formulations, they have developed symbolic interactionist and ethnographic approaches, while many have elaborated poststructuralist analysis emphasizing symbolic codes and discourses. Depending upon their methodological orientation, some embrace the impact of structures while others favor the use of interpretative approaches to understanding culture.

Sociologists of culture have confronted American based models with ideas and models of European contemporaries: Bourdieu, Giddens, Habermas, or Bauman, among others, though without accepting their formulations uncritically. Moreover, many are less committed to a conception of sociology as a purely "objective" science, and see it as a discipline embedded in a world of moral and political choices among competing values. I would argue that this perspective must be encompassed in our analyses rather than be allowed to creep in and contaminate our findings. This is all the more vital because of the opening up to legitimacy areas of concern that had been thoughtlessly (or deliberately?) excluded in the past. In any case, methodologies of whatever kind need to be related both to humanistic concerns, including the precise meanings that are constructed in language, norms, values, beliefs, and to socio-economic structural bases. All in all, cultural sociologists have by theory, example and practice much to contribute to the vital and potentially dangerous debates that pervade such domains as that of "identity," including ethnicity, gender, race, and many others with a strongly political loading.

But pursuing questions of meaning, identity, and value in terms of American society alone is clearly not enough. American sociologists are bursting the bonds of the narrow parochialism of the past into the adventurous terrain of global processes and their consequences. This new cosmopolitanism provides challenges that the versatility of approaches and conceptualizations of social science and the humanities together may help us meet.

So why, in response to Diana Crane's invitation to think about a cutting-edge for the sociology of culture, do I feel some disappointment? I guess it has something to do with the very richness 
of the meanings we have given to culture in the ways I have suggested, while at the same time realizing that this wealth, to whose increase I myself have contributed, comes at some costs. In 1988, when the Culture Section was only a couple of years old, two of our members, Jeffrey Goldfarb and Liah Greenfield, invited participants to enter into a dialogue about the aim of sociology of culture. Greenfield, referring to Weber's "perspective" emphasized the proper direction for a sociology of culture in "symbolic representations of the action situation" in general. Goldfarb argued against her position, preferring to stress Weber's separation of spheres, which leads us to appreciate "the artifacts and accomplishments of the arts and sciences on their own terms" in the context of a "differentiated modern world." In my view, as an attempt to reconcile their positions, I argued that a sociology of culture represented "a capacious field ... whose folds can encompass a range of approaches and subjects once excluded through a premature semi-codification of knowledge." At that early moment in the existence of the Culture Section, I called upon sociologists to engage in "the construction of our own field, with the awareness that however it came out, we begin with no preordained final position."

On the whole I think most American sociologists of culture should be pleased, as I am, at how much we have accomplished in a very short time. We have even begun to talk to each other across the barriers of discourse and textual analysis usually associated with culture studies, postmodernism, postructuralism, history. On the other hand, it gives me some ground for concern (and red-faced chagrin, if truth be told). In looking over one source of data that many of us find useful, the column "New Books of Note" in the Culture newsletter, a service rendered us by Richard Peterson (starting, as far as I can tell, in 1987) has been helpful to both faculty and students. Peterson doesn't confine himself to the sociological discipline alone, but includes works that he thinks will interest section members, incorporating books that members bring to his attention. What it reveals is that "culture" has truly expanded. It takes in a vast range of domains, from a variety of perspectives. But something is missing. 
What is missing is the domain of the fine arts. Should one regret that loss, or be grateful that the lessons preached by many of us - Howard Becker, Pierre Bourdieu, as well as myself - to resist the ideology-laden attempt to privilege high culture at the expense of other forms of cultural production - has been learned? Unfortunately, as a brief perusal of one important source of information on the frequency with which sociologists publish studies on the fine arts reveals that the low amount of attention they devoted to this field a decade and a half has hardly changed [See Figure 1].

\section{Figure 1 - Percent of Fine Arts in "Books of Note" Column}

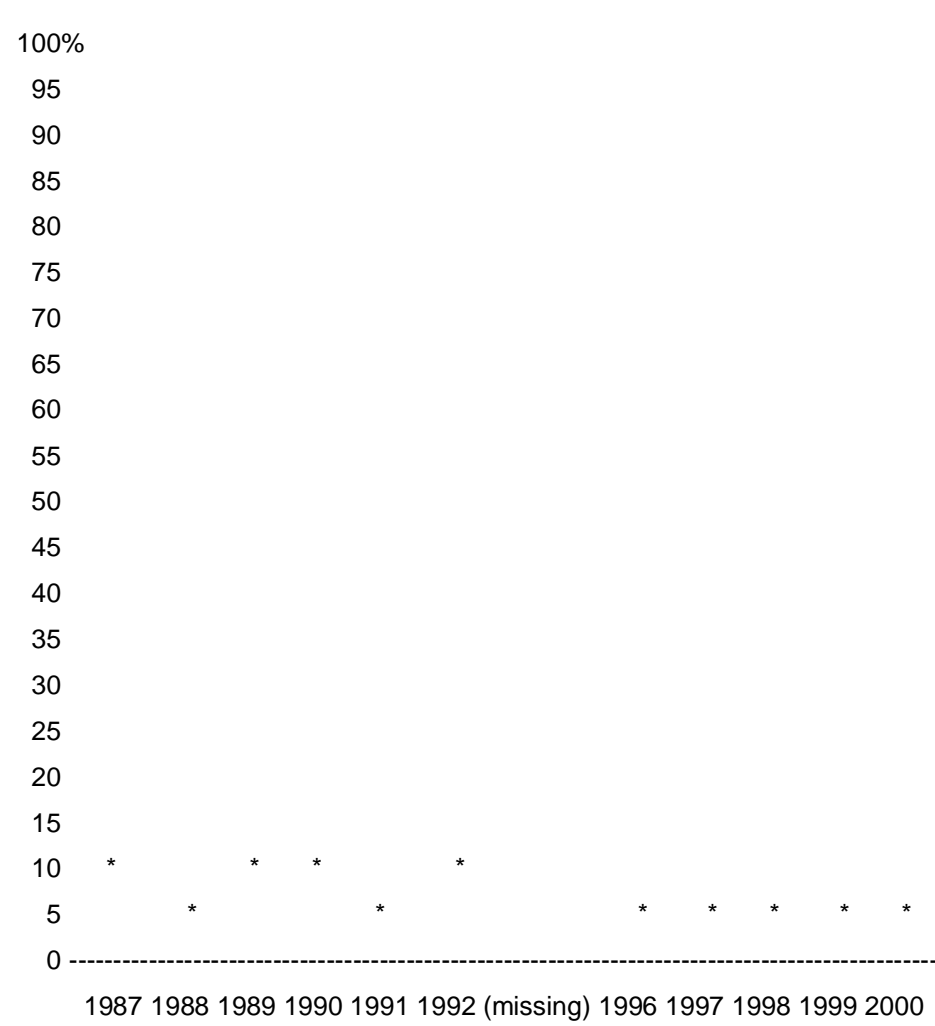


As if this - at best, static situation - were not bad news enough for those who did not expect a diverse, multivocal field to overwhelm the realm of what has awkwardly been termed "serious" art and music, a look at the very fine books published by the Culture Section suggests that they follow suit. Whereas Diana Crane's collection includes the essay on art by Anne Bowler (1994), the more recent collection edited by Elizabeth Long has not even one such essay. The contribution that comes closest to the subject is the article by Andrew Goodwin and Janet Wolff (1997), in which aesthetics is made to enter into their analysis.

The situation after a couple of decades of growth in the analysis of culture by sociologists has not benefited the fine arts and music, even though those subjects continue to flourish among European sociologists, both in Britain and on the continent. Perhaps the way to deal with this persistent lacuna is simply to make the domain a central area of research. This is what I hope to do in the very near future, and I invite anyone who wishes to join me to come along!

I am far from being alone in lamenting the relative neglect of the arts (worse in the US than in Europe) among sociologists. But it is all the more ironic because cultural sociology - which is now so central to the discipline as a whole - developed over the past two decades out of the sociology of the arts. But for those who consider the aesthetic dimension as central to humanity, there is reason for hope. As a look at several essays in the new Blackwell Companion for the Sociology of Culture shows, there is a "new" cultural sociology with the aesthetic dimension at its core. Interestingly, this "aesthetic turn" was central to the thinking of the Companion's coeditors Mark D. Jacobs and Nancy Weiss Hanrahan, who actively participated in the 2001 Forum.

By way of example, I outline the development of the aesthetic canon through the modern period in Europe, and its apparent dissolution in the postmodern one. But there is a puzzle in this seemingly straightforward narrative. If the categories and distinctions that once supported the canon have dissolved, if more types of work are 
considered art, if there is now a plurality of gatekeepers and indeed, of criteria of aesthetic value, how is it that there is still something we call Art? How do we explain the persistence of Art in contemporary conditions, in which the cultural authority to name it has been dismantled?

A second participant, Antoine Hennion explores the quirky, seemingly eccentric, habits and dispositions of the "amateur," such as the music lover who knows the location of every $\mathrm{CD}$ on his shelf but whose filing system defies rational categories. Challenging Bourdieu's notion of taste as a classification system that can be mapped on to other social indicators, he analyzes the interactions, devices, bodies and objects through which taste comes to have these very particular forms. Taste, he argues, is a reflexive activity: through these modalities, both the specific competencies of the amateur and the repertoire of objects that she values are produced.

Tia de Nora considers how we use music to explore our moods, get ready for work, remind us of people we love or set the stage for parties, sex, or shopping. In her view, music is not a structure; that is, not something that acts on individuals, but a resource for action, for the production of self, emotional states, styles and interaction situations. Her model of aesthetic agency provides an alternative to idea that music reflects, anticipates, or is structurally analogous to social developments or cognitive styles and points to role of material culture in configuring subjectivity.

Jan Marontate analyzes the changing nature of museum practices as these institutions shift from sites of cultural authority to sites for negotiation between museum experts, groups that are the subjects of museum exhibitions, and the publics that the institution serves. No longer the arbiter or finality, or interpreter of culture, museums must respond to the claims of different groups to authority over their own material artifacts and cultural information. These changing ideas about cultural rights, authenticity and cultural authority affect not only the curatorial decisions of museums, but virtually every museum practice (from the handling and restoration of objects in 
collections to the manner in which exhibition catalogs are written) and engage the public as an active participant in the creation of shared practices and values.

"How can we remember terror, and how can we forget it?" is the question posed by Anna Lisa Tota in her analysis of the commemorations of the 1980 Bologna massacre and the 1969 bombing in Milan. She argues that the commemoration of terror requires the construction of adequate sites and objects of memory, including memorial plaques at the train station in Bologna and "Bus 37," used to transport the dead from the scene. But it was the vitality of local councils, associations of the victims' families and their collective ability to press the state for resources that ultimately made the difference between the remembrances of Bologna and the forgetting in Milan.

Robin Wagner-Pacifici argues that in liminal moments of rapid change, multiple perspectives and instant information, the witness who can render, record and remember becomes especially important in making the world intelligible. But the location of the witness in both time and space generates a number of dilemmas. All witnesses, whether third party observers or actual survivors, operate both inside and outside of an event; they are at once implicated in it and freed from its mandates. How will the witness recount and represent the act after its occurrence? In this regard, artists and writers are particular kinds of witnesses. Their paintings, play, poems, etc. are signatures by which they subscribe to the scene.

Mark D. Jacobs brings an aesthetic sensibility to the analysis of recent corporate and governmental scandals. These struggles between good and bad faith take on classic dramatic forms of tragedy, comedy and irony; the narrative understanding of scandals is intertextual. Techniques of narrative and dramaturgical analysis are necessary to reveal the full extent to which the unfolding of scandals corrupts (rather than reinforces) the very bases of accountability.

Nancy Weiss Hanrahan also uses music as both subject matter and as a template for the structure of social theory. She has developed a model of cultural systems that incorporates temporality on all levels 
- the symbolic order, the institutional order, and that of social experience - and in which musical process is used to reconceptualize social reproduction and the possibilities of social change.

Beyond this important collection of essays in the sociology of culture, which are likely to set the agenda for research in the next decade at least, other works that give aesthetics importance, are beginning to appear. One of those is Bonds of Civility: Aesthetic Networks and the Political Origins of Japanese Culture, by Eiko Ikegami, which has just been published by Cambridge University Press (2005). This book is quite extraordinary in its originality, creative orientation, and combines scholarly heft with a delicate touch. She works on state formation, bureaucratic development and the role of aesthetics in a comparative perspective. This pathbreaking work follows upon Ikegami's earlier work, Taming of the Samurai: Honorific Individualism in the Making of Modern Japan. She brings her distinctive approach to the analysis of state theory in the tradition of Clifford Geertz's NEGARA, integrating the aesthetic dimension into the state building process. Moreover, her book explicitly incorporates some of the most important conceptual frameworks of analysis into these processes of political development : network analysis, and the role of commercial publishing that provided a vital medium for the dissemination of cultural and aesthetic forms that have come to be associated with Japanese identity.

Whereas her book is essentially a case study of a particular nation, her sociological sense enables her to use to the fullest the insights expressed by the great European scholar, Norbert Elias, whose bringing into play of such cultural products as books of etiquette in the civilizing process and state formation continues to guide social scientists. The result of her impressive historical scholarship is a book that does for Japanese society what Bourdieu accomplished for French: she disinters the elemental forms of cultural structures that remain as compressed history or "structuring culture". Among the important art forms whose construction she shows intersects with the political, economic, and social development of Japan are the performing arts, poetry, and the associational life that grew abundantly both among the creators and their presumptive publics. 
Appropriately, she focuses attention on the Tokugawa period, a predominantly feudal regime, in which artistic and poetic networks counteracted the political center. The Japanese case, however, does not stand alone in her formulation. Implicitly or explicitly, Ikegami makes it encompass a comparative analysis with European developments as expressed by Habermas, but one in which rather than a single rational civil community, a multiplicity of communicative publics of greater or lesser durability emerge. The implications of these processes in different yet intersecting domains will give us a great deal to incorporate into our understanding of social, cultural, and political transformations in a globalized world.

While aesthetics is a crucial feature of their work, the contributions of these scholars to the study of culture go far beyond the arts per se. Collectively, they address issues of social interaction, forms of agency, cultural authority, self-realization and play, cultural diversity and conflict, the temporal dimension of social experience, normative issues of civil society, and the structure of social theory. Though we now tend to think of culture as the medium of lived experience, rather than as a distinct system comprising various subsystems, art is reclaiming its centrality to the conceptualization of culture. "Bringing the Arts Back In," or "re-aestheticizing the culture concept" holds out exciting promise for advancing the study of culture. As scholars have made the study of culture an increasingly pervasive part of the social sciences and humanities, the concept of culture itself has become progressively "thinned" down. We may now be able to perceive culture at work in every crevice of discourse and social interaction; but ironically that pervasive presence no longer has the analytic power of, say, Max Weber's famous "switchman"the power to steer entire national societies towards paths of economic and political development characteristic of this-worldly asceticism rather than other-worldly mysticism.

"Bringing the arts back in" is a way of thickening the contemporary conception of culture, to restore its full analytic power. It is also a way of cutting through theoretical issues that, although 
central, have become stale. Working through the issue of agency and structure, for example, has been stalemated by its overdetermined nature. Recasting that issue as one of artistic creativity suggests an exciting possibility of resolving the stalemate. Similarly, issues of difference are more productively approached through art than through politics. That art is universal in its nature, but infinitely variable in its interpretation, suggests a model for reconceiving issues of local/global culture.

Finally, bringing the arts back in re-introduces a normative and evaluative dimension to culture with direct relevance to the reconstruction of a democratic public sphere. Culture can be judged, just as can an artwork, by its quality of expression. All art is not equally successful; the degree to which it is formulaic or autonomous is a crucially important variable. Normative issues of "mass culture" and "mass democracy" no longer have the salience they did a halfcentury ago. But the multi-disciplinary study of culture is so important today in large part because culture - culture as the medium of lived experience, the culture that fills in every crevice of discourse and social interaction - establishes the conditions of civil society. Thickening that conception of culture, in part by giving it a normativecritical quality, holds direct promise for improving our civic life.

Resumo: Ascenção e queda da Sociologia da Cultura: trazendo as artes de volta

Este artigo apresenta as discussões internas mais correntes, entre os pesquisadores do campo da sociologia da arte, mais particularmente, os posicionamentos de especialistas, participantes de um fórum em cultura organizado em 2001. No seu texto, Vera Zolberg destaca, sobretudo, a necessidade da sociologia da arte reter tanto as suas raízes humanistas como as científicas. A autora lembra que a sociologia da cultura se desenvolveu a partir da sociologia da arte, nas duas últimas décadas. Em seguida, resume as principais tendências e interesses dos pesquisadores presentes ao fórum, mostrando a fluidez de suas possibilidades e capacidades criativas. Faz referência á produção mais recente, provando que a 
estética se constitui em parte crucial dos estudos sociológicos sobre a arte. Segundo Vera Zolberg, é chegada a hora de trazer as artes de volta.

Palavras-chave: Sociologia, arte, cultura, sociedade e flexibilidade.

\section{Selected references}

BAUBÖCK, Rainer The crossing and blurring of boundaries in international migration: challenges for Social and Political Theory. In: BAUBÖCK, R.; Rundell, J. (Eds). Blurred boundaries: migration, ethnicity, citizenship. Brookfield, Vt: Ashgate Publishing Company, 1999. p. 17-52.

BECKER, Howard S. Art worlds. Berkeley, CA: University of California Press, 1982.

BELL, Daniel. The cultural contradictions of Capitalism. New York: Basic Books, 1996. [With a new Forward to 1978 edition]

BENJAMIN, Walter. The work of art in the age of mechanical reproduction. In: ARENDT, Hannah (Ed.). Illuminations. New York: Schocken, 1969.

BOURDIEU, Pierre Distinction: a social critique of the judgement of taste. Trans. by Richard Nice. Cambridge: Harvard University Press, 1984.

The rules of art: genesis and structure of the literary field. Trans. by Susan Emanuel. Stanford, CA: Stanford University Press. 1995. [Orig. Éditions du Seuil 1992]

BOWLER, Anne. Asylum art: the social construction of an aesthetic category. In: ZOLBERG, V. L.; CHERBO, J. M. (Eds.). Outsider art: contesting boundaries in contemporary culture. New York: Cambridge University Press, 1997.

Methodological dilemmas in the Sociology of Art. In: CRANE, Diana (Ed.). The Sociology of Culture: emerging theoretical perspectives. Cambridge, MA: Blackwell, 1994.

CRANE, Diana. The transformation of the avant-garde: The New York Art World 1940-1985. University of Chicago Press, 1987.

DANTO, Arthur C. The philosophical disenfranchisement of art. New York: Columbia University Press, 1986. 
DANTO, Arthur C. Why does art need to be explained? Hegel, Biedermeier and the intractably avant-garde. In: WEINTRAUB, Linda et al. (Ed.). Art on the edge and over: searching for art's meaning in contemporary society, 1970s-1990s. New York: Art Insights, 1996.

De NORA, Tia. Music in everyday life. Cambridge University Press, 2000.

Di MAGGIO, Paul J. Classification in Art. American Sociological Review, n. 52, p. 440-455, August 1987.

GANS, Herbert J. American popular culture and high culture in a changing class sructure. In: PROSPECTS: an annual of American Cultural Studies 10. Cambridge: Cambridge University Press, 1985.

GERTH, Hans; MILLS, C. Wright. From Max Weber. New York: Oxford University Press, 1946.

GOLDFARB, Jeffrey The persistence of freedom: the sociological implications of Polish Studen Theater. Boulder, Colo: Westview Replica Editions, 1982.

GOODWIN, Andrew; WOLFF, Janet. Conserving cultural studies. In: LONG, Elizabeth (Ed.). From Sociology to cultural studies: new perspectives. Malden, MA: Blackwell, 1997.

GRAÑA, César. The king's shadow: the aesthetic legacy of the aristocracy. In: Meaning and authenticity: further essays in the Sociology of Art. New Brunswick, New Jersey: Transaction Publishers, 1989. p. $139-184$

HAUSER, Arnold. The Social History of Art. New York: Alfred A. Knopf, $1951.4 \mathrm{v}$.

HEINICH, Nathalie. Du peintre à l'artiste: artisans et académiciens à l'âge classique. Paris: Éditions de Minuit, 1993.

IKEGAMI, Eiko. Bonds of civility: aesthetic networks and the political origins of Japanese culture. Cambridge University Press, 2005.

Taming of the samurai: honorific individualism in the making of modern Japan. Cambridge: Harvard University Press, 1997.

KRISTELLER, Paul O. The modern system of the Arts. Journal of the History of Ideas, n. 12, p. 496-527, 1951.

. The modern system of the Arts II. Journal of the History of Ideas, n. 13, p. 17-46, 1952. 
PETERSON, Richard A. Melding ethnographic and humanist definitions of Culture. Culture, 6/3, p. 10-11, Spring 1992.

POGGIOLI, Renato. The theory of the avant-garde. Cambridge: Harvard University Press, 1971.

ROSENBERG, Harold. The anxious object: art today and its audience. New York: Horizon Press, 1964. . The tradition of the new. New York: McGraw Hill, 1965.

SEIDMAN, Steven. The postmodern turn: new perspectives on Social Theory. Cambridge University Press, 1994.

SIMMEL, Georg. The philosophy of money. Ed. by David Frisby, trans. by Tom Bottomore and David Frisby [second enlarged edition]. New York: Routledge, 1990. [orig. 1904]

TÖNNIES, Ferdinand. Community and society. New York: Harper \& Row, 1963.

WILLIAMS, Raymond. Culture. Glasgow: Fontana, 1981.

WITKIN, Robert W. Adorno on Music. New York: Routledge, 1998.

ZOLBERG, Vera L. African legacies, American realities: Art and Artists on the Edge. In: ZOLBERG, V. L.; CHERBO, J. M. (Eds.). Outsider art: contesting boundaries in contemporary culture. New York: Cambridge University Press, 1997.

. Constructing a Sociology of the Arts. New York: Cambridge University Press, 1990. 